УДК 538.9:536.6

\title{
NEW DIRECTION IN LIQUID QUENCHING MEDIA DEVELOPMENT
}

\author{
N.I.Kobasko ${ }^{1}$, PhD, FASM, A.A.Moskalenko ${ }^{2}$, PhD, P.N.Logvinenko ${ }^{3,4}$, Ph.D, V.V.Dobryvechir ${ }^{1}$
}

${ }^{1}$ Intensive Technologies Ltd., 68/1 Peremohy ave., Kyiv, 03113, Ukraine

${ }^{2}$ Institute of Engineering Thermophysics of NASU, 2a, Zhelyabova str., Kyiv, 03057, Ukraine

${ }^{3}$ Institute of Macromolecular Chemistry of NASU, 48 Kharkivske road, Kyiv, 02160, Ukraine

${ }^{4}$ Barkor Ltd, Kyiv, Ukraine

https:doi.org/10.31472/ttpe.3.2019.5

Показано, що на противагу поверхнево-активним речовинам (ПАР), змінюючих суттєво фізичні властивості рідини, ліквідація парової плівки при гартуванні відбувається завдяки утворенню теплоізоляційного покриття на поверхні металу. Це досягається використанням водних розчинів спеціальних полімерів. Теплоізоляційне полімерне покриття зменшує початковий тепловий потік нижче його критичного значення, ліквідуючи парову плівку без суттєвої зміни фізичних властивостей рідини. Базуючись на цьому факті та принципі зниження деформацій, тріщиноутворення і зміцнення матеріалу при інтенсивному гартуванні, запропоновано використовувати низькі концентрації полімерів замість їх високих концентрацій. Це призводить до значного зміцнення металу, економії матеріалів та зростанню довговічності загартованих виробів.
Показано, что в отличие от поверхностно-активных веществ (ПАВ), изменяющих физические свойства жидкости, устранение паровой пленки достигается образованием тонкого полимерного покрытия на поверхности металла. Это осуществляется использованием водных растворов специальных полимеров. Покрытие уменьшает начальный тепловой поток ниже критического значения и тем самым устраняет паровую пленку, не оказывая заметного влияния на физические свойства жидкости. Основываясь на этом факте и принципе снижения деформаций, устранения трещин и существенного упрочнения стали интенсивной закалкой, предложено использовать низкие концентрации разных полимеров вместо их высоких концентраций. Это приводит к существенному упрочнению металла, экономии материалов и увеличению долговечности работы закаленных изделий.
It is shown that in contrast to well known surface active additives (SAA), affecting physical properties of a liquid, the elimination of film boiling during quenching is achieved by creation of the thin polymeric layer on the surface of hardened metal. It is performed by using special polymers of optimal concentration in water. The obtained insulating polymeric layer decreases initial heat flux density below its critical value and by this way eliminates completely the film boiling without affecting clearly the physical properties of a liquid. Based on this fact and on the principle of decreasing distortion, quench crack formation, and increasing strength of material during intensive quenching, it is proposed to use low concentration of special polymers instead of their high concentration in water. All of this results in significant strengthening of metal, saves costly materials, and increases service life of hardened products.

Ref. 15, Table 3, Fig. 7.

Keywords: IQ process, new direction, low convention, special polymers, film boiling elimination, distortion, strength, service life.

$q_{o}-$ initial heat flux density, $\mathrm{MW} / \mathrm{m}^{2}$;

$q$ - reduced heat flux density, $\mathrm{MW} / \mathrm{m}^{2}$;

$\delta$ - thickness of insulating layer, $\mathrm{m}$;

$\lambda$ - thermal conductivity of steel, $\mathrm{W} / \mathrm{mK}$;

$\lambda_{\text {coat }}-$ thermal conductivity of an insulating layer (coating),

$\mathrm{W} / \mathrm{mK}$;

$k_{F}-$ form coefficient;

$R$ - radius, m;

\section{Introduction}

The bell - shaped curve (see Fig. 1) was discovered by authors [1] in 1964. It says that distortion and quench crack formation of steel parts is minimal when performing very slow cooling or extremely high cooling during quenching. Cooling rate of any steel part is a linear function
$D$ - thickness or diameter, $\mathrm{m}$;

$a$ - thermal diffusivity of steel, $\mathrm{m}^{2} / \mathrm{s}$;

$v$ - cooling rate, ${ }^{\circ} \mathrm{C} / \mathrm{s}$;

$\mathrm{Kn}$ - dimensionless Kondrat'ev number;

$\mathrm{K}$ - Kondrat'ev form factor, $\mathrm{m}^{2}$;

$T_{m}$ - bath temperature, ${ }^{\circ} \mathrm{C}$;

$T$ - current temperature, ${ }^{\circ} \mathrm{C}$;

$\tau_{n b}-$ duration of transient nucleate boiling process, $s$.

of dimensionless number $\mathrm{Kn}$ which changes within 0 and 1, i.e. $0<\mathrm{Kn}<1$. As a rule, alloy and high alloy steels are quenched slowly in oils or air flow to receive minimal distortion and avoid crack formation. However, slow cooling in zone I $(0<\mathrm{Kn}<0.2)$ requires more alloy elements in steel to provide needed hardened depth and in many cases 
results in creation of surface tensile stresses. Temperature gradient through section of steel part in zone I is small that decreases probability of quench crack formation. The zone III (see Fig. 1) intensive quenching (IQ) process takes place where temperature gradients and cooling rate are maximal. When Kondrat'ev number $\mathrm{Kn}=1$, surface temperature during quenching of steel parts drops immediately to bath temperature creating maximal temperature gradient. The zone III is called direct convection since there are no nucleate boiling at all. Convection starts from the very beginning of cooling. In zone III distortion is minimal, high surface compressive stresses are formed during intensive quenching preventing quench crack formation. Additional strengthening (superstrengthening) of material is observed here that all together increases significantly service life of hardened steel parts.

A long time this principle was not adopted by industry because customers didn't believe in it. It cannot be - was the answer. After painstaking experiments and many computer simulations made in the USA, Germany and Japan this principle was finally accepted by engineers and is currently successfully used in heat treating industry [2 - 5]. One of many simulations is presented in Fig. 2. As seen from Fig.2, intensive quenching generates surface compressive residual stresses and minimal distortion while quenching in oil results in visible distortion and tensile surface residual stresses in keyway shaft [6].

Based on received results of investigations, there is a possibility to use accelerated cooling during hardening different types of steel parts. In 1987, authors [7] forwarded an idea on designing the accelerated cooling by means of artificially created insulating layer on the surface of steel parts before their hardening. In 1996 authors [8, 9] noticed that low concentration (1\%) of UCON E polymer in water significantly intensifies process of quenching. Cooling rate of standard silver probe $20 \mathrm{~mm}$ in diameter during quenching in $1 \%$ water solution of UCON E was $674{ }^{\circ} \mathrm{C} / \mathrm{s}$ while during quenching in water was only $231{ }^{\circ} \mathrm{C} / \mathrm{s}$. Full film boiling during quenching in water lasts for 7 seconds while in $1 \%$ polymer solution it lasts only for $0.2 \mathrm{sec}$. However there are no data concerning intensity of cooling of large steel parts in $1 \%$ water polymer solutions of inverse solubility. The paper considers this issue.

\section{Elimination of film boiling by insulating thin layer}

In contrast to well know approach of elimination film boiling process during quenching that uses surface active additives (SAA), the problem of film boiling elimination is successfully solved by use low concentration of inverse solubility polymers $(1 \%)$ that create thin surface insulating layer during hardening of steel parts. Due to presence a thin insulating layer, initial heat flux density drops below its critical value preventing effectively any film boiling. The decrease of initial heat flux density qo is calculated by Eq. (1) [10]:

$$
q=\frac{q_{0}}{\left(1+2 \frac{\delta}{R} \frac{\lambda}{\lambda_{\text {coat }}}\right)} .
$$

The new approach requires new technique for investigating mechanism of insulating layer formation, taking into accounts its thickness variation and thermal properties of insulating material. To properly investigate such processes,

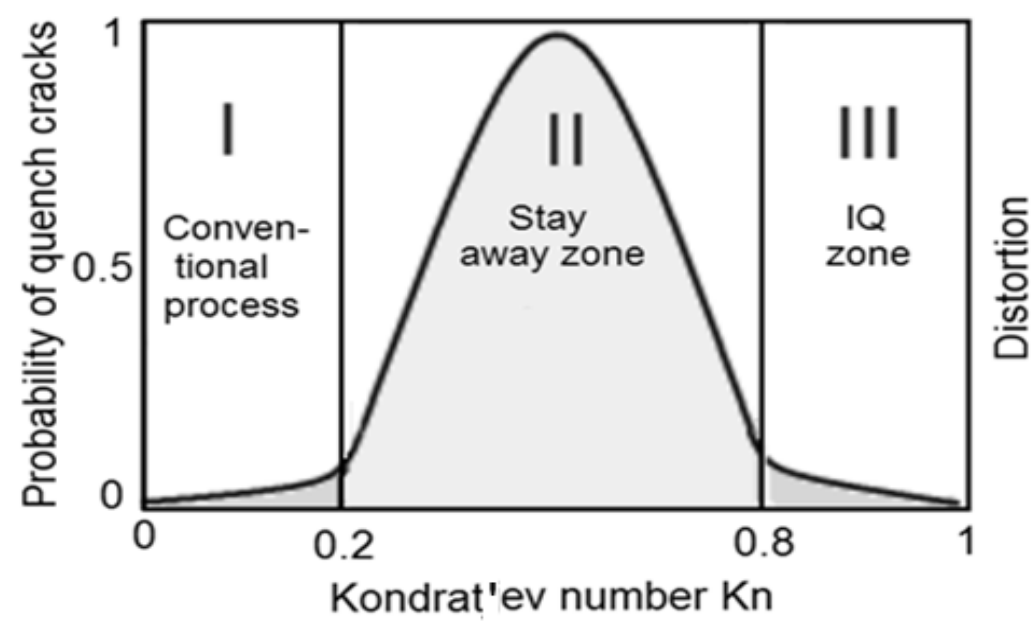

Fig. 1. Probability of quench crack formation and distortion versus Kondrat'ev number Kn. 
one should measure accurately surface temperature of the probe during quenching, surface temperature of insulating layer and its thickness variation that is very complicated task. Along with the surface temperature recording during quenching of the probe, authors [8,9] used sonar system for careful investigation process of quenching (see Fig. 3).

It should be noted that cooling intensity of inverse solubility polymers were widely investigated in former
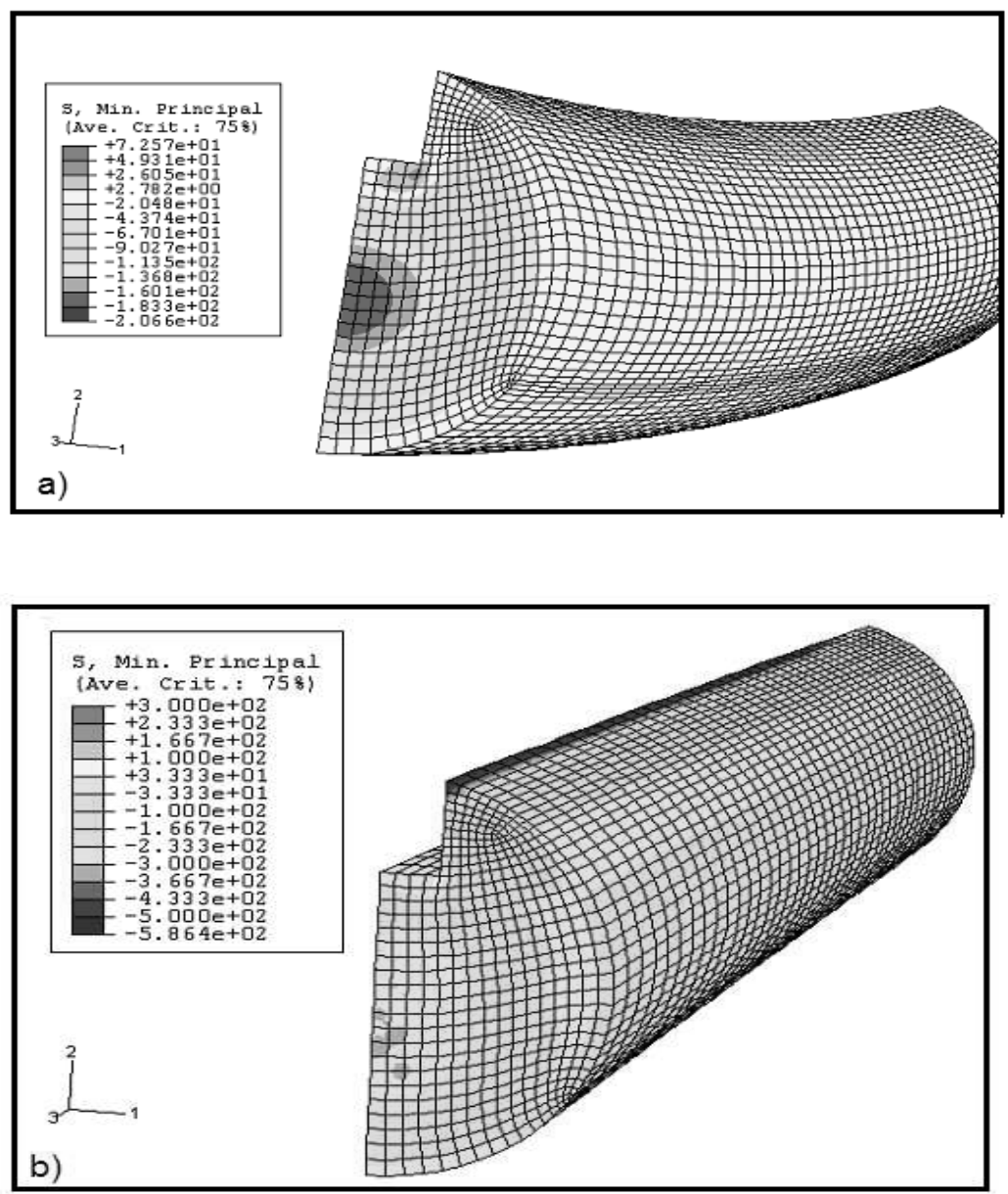

Fig. 2. Minimum principal residual stresses in keyway shaft after quenching in oil (a) and after IQ process (b) according to author [6].

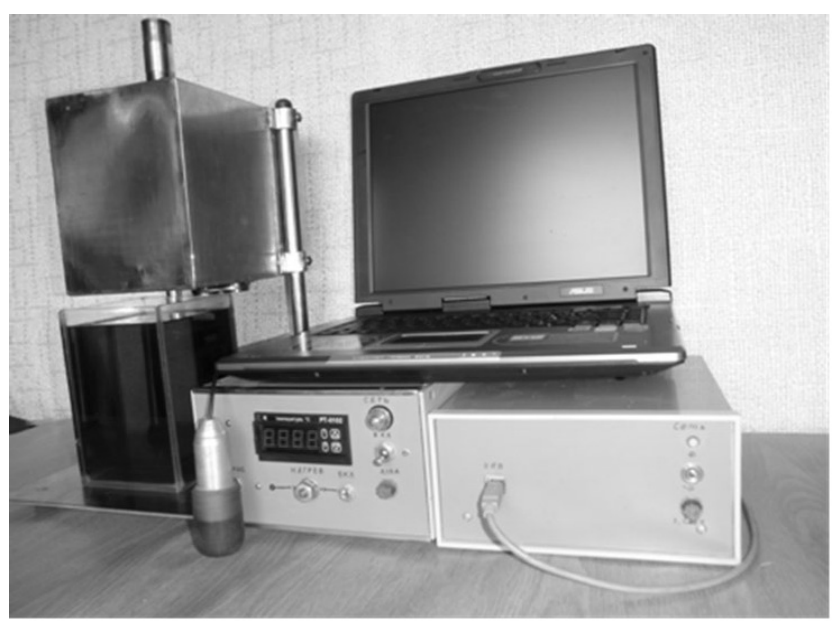

Fig. 3. Thermo - sonar system for measuring cooling intensity of liquid quenchants. 
Union Carbide Corporation (USA) using different diameters of cylindrical probes $(12.7 ; 25.4 ; 38.1 ; 50.8 \mathrm{~mm}$ or $0.5 ; 1$; 1.5 and 2 inches) instrumented with one thermocouple at the center of the probes. Some results of these investigations one can get from the book [2]. Investigations were performed with concentration $5 \%, 10 \%, 20 \%$, and $30 \%$ inverse PAG solubility polymers in water. Similar measurement is shown in Fig. 4 which was made by authors during quenching the cylindrical probe $50 \mathrm{~mm}$ in diameter in $1 \%$ UCON E water solution at room temperature $23^{\circ} \mathrm{C}$.

To be sure that quenching in $1 \%$ water polymer solution of UCON E was intensive enough and film boiling was absent, cylindrical probe $50 \mathrm{~mm}$ in diameter, instrumented with three thermocouples, was quenched in $14 \%$ water solution of $\mathrm{NaCl}$ at $23^{\circ} \mathrm{C}$. Results of experiments are provided in Fig. 5.

Core cooling rates and core cooling curves are similar for both experiments (see Fig. 4 and Fig. 5). Fig. 6 provides results of simplified calculations after taking into account the self regulated thermal process [2].

More detail information on the intensity of cooling in low concentration of inverse solubility polymer, water salt solution and results of simplified calculations are provided in Table 1.

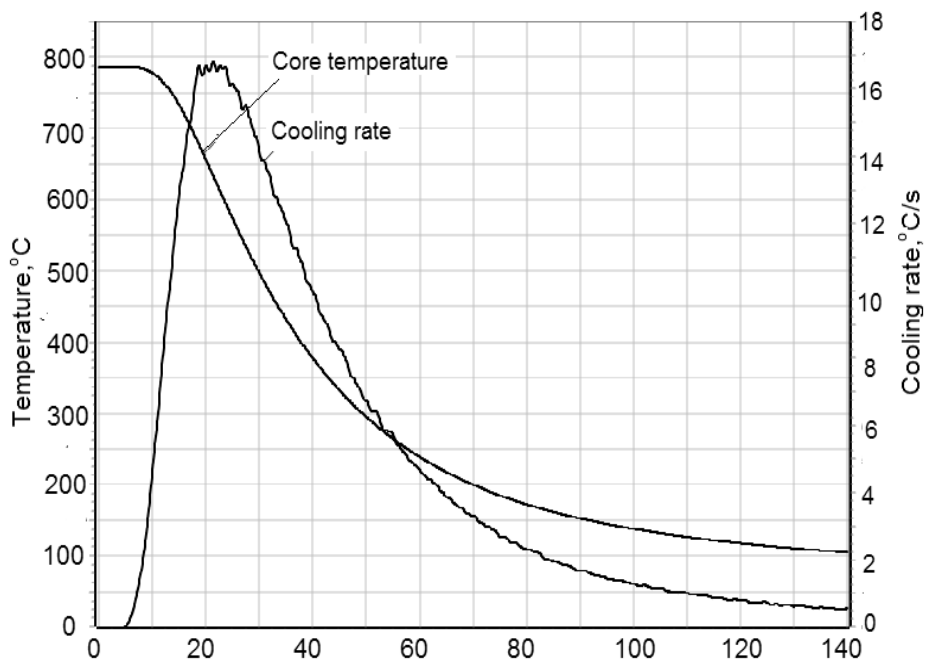

Fig. 4. Temperature and cooling rate curves versus time during quenching $50 \mathrm{~mm}$ cylindrical stainless probe in $1 \%$ water solution of $U C O N E$ at $23^{\circ} \mathrm{C}$.

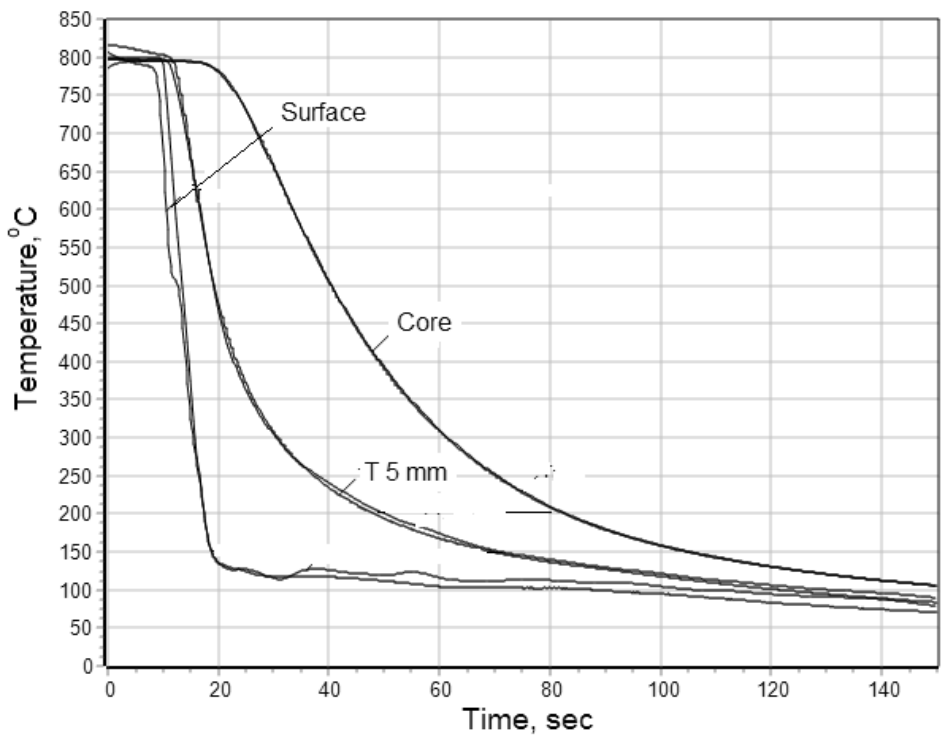

Fig. 5. Temperature curves versus time during quenching $50 \mathrm{~mm}$ cylindrical stainless probe in $14 \%$ water solution of $\mathrm{NaCl}$ at $23^{\circ} \mathrm{C}$ received by experiment. 


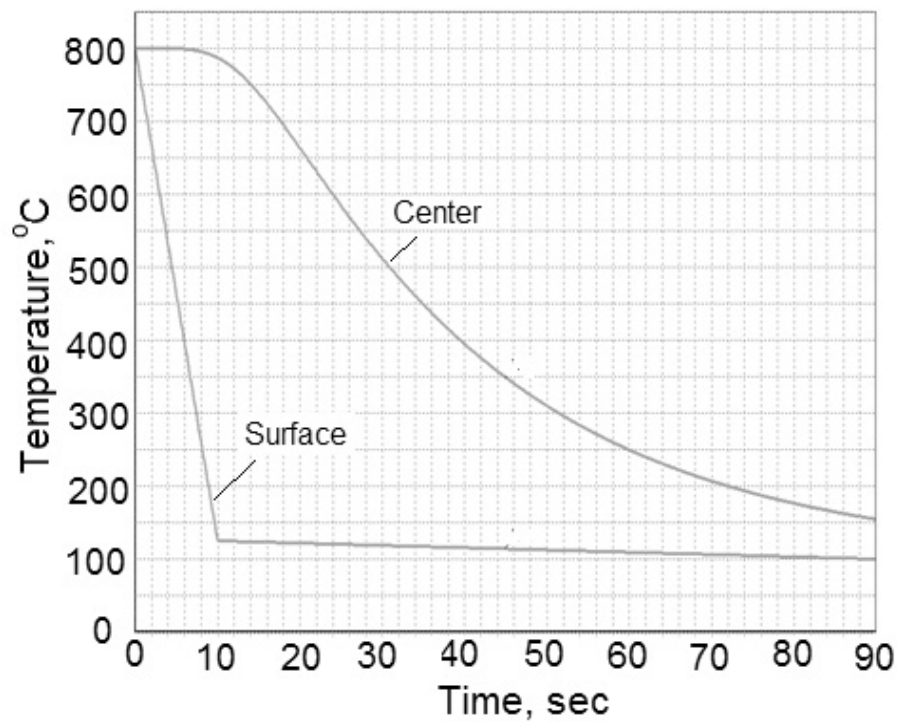

Fig. 6. Temperature curves versus time during quenching $50 \mathrm{~mm}$ cylindrical stainless probe in $14 \%$ water solution of $\mathrm{NaCl}$ at $23^{\circ} \mathrm{C}$ received by simplified calculation proposed by author [5].

Table 1. Comparison of cooling time measurement within different temperature intervals during quenching cylindrical probe $50 \mathrm{~mm}$ in diameter in water salt solution and low concentration of UCON E in water

\begin{tabular}{|l|c|c|c|}
\hline Temperature interval & $\mathbf{7 5 0}^{\circ} \mathbf{C}-\mathbf{3 0 0}^{\circ} \mathbf{C}$ & $\mathbf{7 5 0}^{\circ} \mathbf{C}-\mathbf{4 0 0}^{\circ} \mathbf{C}$ & $\mathbf{7 5 0}^{\circ} \mathbf{C}-\mathbf{5 0 0}^{\circ} \mathbf{C}$ \\
\hline $\begin{array}{l}\text { Cooling time in sec when quenching in } 14 \% \text { water } \mathrm{NaCl} \\
\text { solution at } 23^{\circ} \mathrm{C} \text { (Experiment) }\end{array}$ & 36 & 24 & 16.3 \\
\hline $\begin{array}{l}\text { Cooling time in sec when quenching in } 14 \% \text { water } \mathrm{NaCl} \\
\text { solution at } 23^{\circ} \mathrm{C} \text { (Simplified calculation) }\end{array}$ & 37 & 25.3 & 16.6 \\
\hline $\begin{array}{l}\text { Cooling time in sec when quenching in } 1 \% \text { water solution } \\
\text { of inverse solubility polymer }\end{array}$ & 35 & 24 & 17 \\
\hline
\end{tabular}

For simplified calculation was used duration of boundary boiling layer formation and duration of transient nucleate boiling process which was calculated by equation (2) [5]:

$\tau_{n b}=\Omega k_{F} \frac{D^{2}}{a}$.

The value $\Omega$ is a function of the convective Biot number when initial temperature To is fixed at $850{ }^{\circ} \mathrm{C}$ and bath temperature is fixed at room temperature [5].

Comparison of cooling time measurement within different temperature intervals during quenching cylindrical probe 50 $\mathrm{mm}$ in diameter in $14 \%$ water salt solution of $\mathrm{NaCl}, 1 \%$ concentration of UCON E in water at $23^{\circ} \mathrm{C}$ and results of simplified calculations are shown in Table 1.

As seen from Table 1, intensity of cooling in water salt solution and low concentration UCON E in water is almost the same. Moreover, the surface cooling curve temperature shows (see Fig. 5) that film boiling was completely absent and surface temperature drops rapidly almost to boiling point of solution and then is kept at this level for relatively a long time. We can conclude that the same is observed on the surface of polymeric layer. Such approach can be used for investigation of the behavior of polymeric layers during quenching in water polymer solutions of inverse solubility.

It makes sense to compare intensity of cooling during quenching the cylindrical probe $50 \mathrm{~mm}$ in diameter in water solutions of different concentrations. Such comparison is provided in Table 2.

The effective Kondrat'ev numbers Kn were calculated using universal correlation for cooling rate $\mathrm{v}$ determination (see Eq. (2)):

$$
v=\frac{a K n}{K}\left(T-T_{m}\right)
$$


Note that effective numbers Kn can be used only for core cooling rate and core cooling time evaluation and cannot be used for temperature fields prediction.

Similar calculations were performed for mineral oils with and without polymer addition. As seen from Fig. 7, the addition of PIB to mineral oil decreases or completely eliminates full film boiling.

Video observation showed that during quenching in mineral oils with PIB additives the polymeric coating is formed on the surface of a probe.

To compare intensity of cooling in water salt solution and low concentration of inverse solubility polymer with oil quenching, similar calculations were performed for oils which are shown in Table 3
As seen from Table 2 and Table 3, the cooling rate of large cylindrical probe $50 \mathrm{~mm}$ in diameter during quenching in water polymer solution (1\%) of UCON E is 6 times larger as compared with oil quenching.

During quenching in water polymer solutions of low concentration accelerated and uniform cooling is provided which should be interrupted at proper time [14]. For this purpose the software was designed by ITL Co (see www. itl.kiev.ua).

\section{Discussion}

The new direction of controlling cooling intensity of liquid quenchants requires development appropriate software and special tools for careful investigation of the

Table 2. Effective Kondrat'ev number Kn during quenching cylindrical stainless probe $50 \mathrm{~mm}$ in diameter in water solutions of UCON E of different concentration and agitation $0.51 \mathrm{~m} / \mathrm{s}$

\begin{tabular}{|c|c|c|c|}
\hline Concentration of UCON E & $\mathbf{2 0 \%}$ With agitation & $\mathbf{5 \%}$ With agitation & $\mathbf{1 \%}$ No agitation \\
\hline $\mathrm{Kn}$ & 0.44 & 0.51 & 0.64 \\
\hline
\end{tabular}

Table 3. Effective Kondrat'ev number Kn during quenching of cylindrical stainless probe $50 \mathrm{~mm}$ in diameter in mineral oils at $43^{\circ} \mathrm{C}$

\begin{tabular}{|c|c|c|}
\hline Type of oil & No agitation & Agitation 0.51 m/s \\
\hline Houghton K & 0.22 & 0.31 \\
\hline Amolite 22 & 0.1 & 0.28 \\
\hline
\end{tabular}

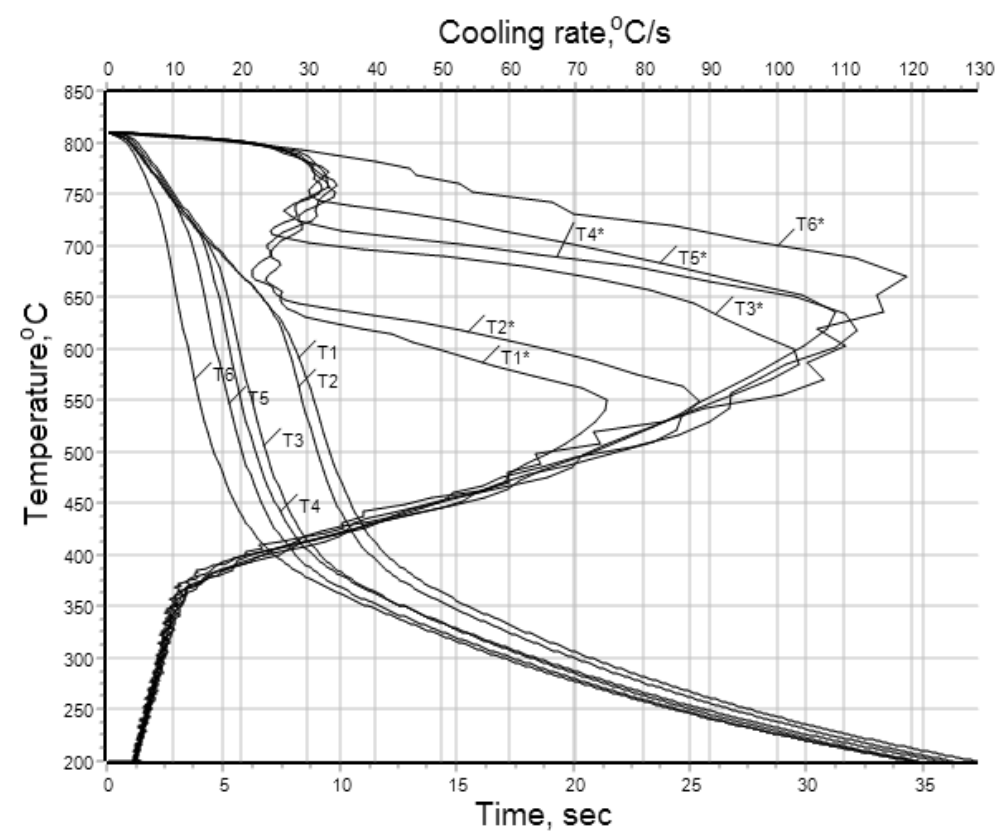

Fig. 7. Effect of PIB (polyisobutylene polymer) concentration in mineral oil I-20A on film boiling elimination depending on its content, $w$ t $\%$ [11, 12, and 13]: T1-0\%, T2-0.5\%; T3-1.0\%, T4-1.5\%, T5-2.0\%, T6-3.0\%. 
behavior of insulation layer formed during quenching on the surface of steel parts. Authors of the current investigation made only the first step showing benefits of thin insulating layers. The next step should be careful investigation of the kinetics of insulation layer formation, its thickness variation, thermal conductivity values evolution, and possible development of the new materials that create insulating layers during quenching. For this purpose along with the traditional standard probe with one thermocouple at the center, it should be used a special probe with many thermocouples instrumented through section [15] and directly on the surface of the probe to receive data suitable for solving inverse problem concerning behavior of insulating polymeric layer. Beneficial way, along with the initial heat flux decreasing, could be the possibility of protection metal from corrosion. These important for the practice problems should be tackled by investigators in the nearest future.

\section{Summary}

The essence of the new approach consists in adding a small amount of polymer to liquid quenchants for creating a thin polymeric insulating layer on the surface of the part being quenched. This insulating layer reduces the initial heat flux density from the part surface below the critical heat flux density preventing completely the film boiling process. This is in contrast with the known method of using surface active materials (SAM) for affecting critical heat flux densities. The elimination of the film boiling process can result in a complete elimination of the double distortion effect for machine components that takes place during quenching parts in liquid media (for example, different kinds of gears). Since a USA company has expressed an interest in evaluating of the proposed approach with its further commercialization in the States, it makes sense to pay more attention to this method for its further appropriate development.

\section{REFERENCES}

1. Kobasko, N.I., Prokhorenko, N.I., Effect of quenching rate on the formation cracks in steel 1045, Metal Science and Heat Treatment, Vol. 6, No.2, 1964, pp. $104-106$.

2. Kobasko, N.I., Aronov, M.A., Powell, J.A., Totten, G.E., Intensive Quenching Systems: Engineering and Design, ASTM International, W. Conshohocken, USA, 2010, 234 p. doi: $10.1520 / \mathrm{mnl} 64-\mathrm{eb}$

3. Rath, J., Luebben, T., Hoffmann, F., Zoch, H.W., Generation of compressive residual stresses by high speed water quenching, International Heat Treatment and Surface Engineering, 4 (4), 2010, 156 - 159.

4. Kobasko, N.I., Aronov, M.A., Ichitani, K., Hasegawa, M., Noguchi, K., High compressive residual stresses in through hardened steel parts as a function of Biot number, Resent Advances in Fluid Mechanics, Heat \& Mass Transfer and
Biology, WSEAS Press, Harvard, pp., 2012, pp. 36 - 40. ISBN: 978- 1-61804-065-7.

5. Kobasko, N.I., Transient nucleate boiling as a basis for designing austempering and martempering new technologies, SSRG International Journal of Applied Physics (SSRG-IJAP), 2019, Vol. 6, Issue 2, pp. 5 - 13, ISSN: $2350-0301$.

6. Ferguson, B.L. Applying DANTE Heat Treat Modeling to Intensive Quenching, Presentation at the Intensive Quenching Workshop held on April 24 in Cleveland, Ohio, USA, 2013.

7. Kovalenko. G.V., Kobasko, N.I., Khalatov, A.A., A method of Hardening of Steel Parts, USSR Certificate No. 1355634, 1987.

8. Kobasko, N. I., Moskalenko, A. A., Intensification of quenching by means of use water polymer solutions, Promyshlennaya Teplotekhnika, 18 (6), 1996, pp. 55-60.

9. Moskalenko, A. A., Kobasko, N. I., Tolmacheva, O. V., Totten, G. E., Webster, G. M. Quechants Characterization by Acoustical Noise Analysis of Cooling Properties of Aqueous Poly (Alkylene Glycol) Polymer Quenchants. Proc. of the 2nd Int. Conf. on Quenching and Control of the Distortion, (USA), 1996, pp.117-122.

10. Kobasko, N. I., Real and Effective Heat Transfer Coefficients (HTCs) Used for Computer Simulation of Transient Nucleate Boiling Processes during Quenching. Materials Performance and Characterization, 2012, 1 (1), doi: $10.1520 / \mathrm{mpc}-2012-0012$.

11. Logvynenko, P. N., Karsim, L. O., Riabov, S. V., Moskalenko, A. A., Kobasko, N. I., Oil quenchant, UA Patent № 104380, 2016.

12. Logvynenko, P. N., Moskalenko, A. A., Kobasko, N.I., Karsim, L. O., Riabov, S. V., Experimental Investigation of the Effect of Polyisobutilene Additives to Mineral Oil on Cooling Characteristics, Materials Performance and Characterization, 2016, 5 (1), doi: 10.1520/ mpc20150072.

13. Kobasko, N.I., Moskalenko, A.A., Logvinenko, P.N., Totten, G.E., Dobryvechir, V.V., New Era in Designing and Governing Cooling Intensity of Liquid Quenchants to Decrease Distortion, International Journal of Current Research, 2018, Vol.10, Issue 8, pp. 72631- 72636.

14. Kobasko. N.I., High Quality Steel vs Surface Polymeric Layer during Quenching, Lambert Academic Publishing, 2019, 102 p. ISBN: 978-613-9-45596-6.

15. Liscic, B., Measurement and Recording ofQuenching Intensity in Workshop Conditions Based on Temperature Gradients. Materials Performance and Characterization, 2016, 5 (1), 209-226. doi: 10.1520/ mpc20160007. 


\section{НОВИЙ НАПРЯМОК В РОЗРОБЦІ РІДКИХ ГАРТУВАЛЬНИХ СЕРЕДОВИЩ}

М.І. Кобаско ${ }^{1}$, к.т.н., А.А. Москаленко ${ }^{2}$, к.т.н., П.М. Логвіненко ${ }^{3,4}$, к.т.н., В.В. Добривечір ${ }^{1}$

${ }^{1}$ ТОВ Інтенсивні Технологї̈, Київ, Україна

${ }^{2}$ Інститут технічної теплофізики НАН Укрїни, вул. М. Капніст, 2а, Київ, 03057, Україна

${ }^{3}$ Інститут хімії високомолекулярних сполук НАН України

${ }^{4}$ ТОВ Баркор, Київ, Україна

https:doi.org/10.31472/ttpe.3.2019.5

Показано, що на противагу поверхнево-активним речовинам (ПАР), змінюючих суттєво фізичні властивості рідини, ліквідація парової плівки при гартуванні відбувається завдяки утворенню теплоізоляційного покриття на поверхні металу. Це досягається використанням водних розчинів спеціальних полімерів. Теплоізоляційне полімерне покриття зменшує початковий тепловий потік нижче його критичного значення, ліквідуючи парову плівку без суттєвої зміни фізичних властивостей рідини. Базуючись на цьому факті та принципі зниження деформацій, тріщиноутворення і зміцнення матеріалу при інтенсивному гартуванні, запропоновано використовувати низькі концентрації полімерів замість їх високих концентрацій. Це призводить до значного зміцнення металу, економії матеріалів та зростанню довговічності загартованих виробів.

Бібл. 15 , табл. 3 , рис. 7.

Ключові слова: інтенсивне гартування, новий напрямок, низька концентрація, спеціальні полімери, застереження плівкового кипіння, деформації, міцність, довговічність.

1. Kobasko, N.I., Prokhorenko, N.I., Effect of quenching rate on the formation cracks in steel 1045, Metal Science and Heat Treatment, Vol. 6, No.2, 1964, pp. $104-106$.

2. Kobasko, N.I., Aronov, M.A., Powell, J.A., Totten, G.E., Intensive Quenching Systems: Engineering and Design, ASTM International, W. Conshohocken, USA, 2010, 234 p. doi: $10.1520 / \mathrm{mnl} 64-\mathrm{eb}$

3. Rath, J., Luebben, T., Hoffmann, F., Zoch, H.W., Generation of compressive residual stresses by high speed water quenching, International Heat Treatment and Surface Engineering, 4 (4), 2010, 156 - 159.

4. Kobasko, N.I., Aronov, M.A., Ichitani, K., Hasegawa, M., Noguchi, K., High compressive residual stresses in through hardened steel parts as a function of Biot number, Resent
Advances in Fluid Mechanics, Heat \& Mass Transfer and Biology, WSEAS Press, Harvard, pp., 2012, pp. $36-40$. ISBN: 978- 1-61804-065-7.

5. Kobasko, N.I., Transient nucleate boiling as a basis for designing austempering and martempering new technologies, SSRG International Journal of Applied Physics (SSRG-IJAP), 2019, Vol. 6, Issue 2, pp. 5 - 13, ISSN: $2350-0301$.

6. Ferguson, B.L.Applying DANTE Heat Treat Modeling to Intensive Quenching, Presentation at the Intensive Quenching Workshop held on April 24 in Cleveland, Ohio, USA, 2013.

7. Kovalenko. G.V., Kobasko, N.I., Khalatov, A.A., A method of Hardening of Steel Parts, USSR Certificate No. 1355634, 1987.

8. Kobasko, N.I., Moskalenko, A.A., Intensification of quenching by means of use water polymer solutions, Promyshlennaya Teplotekhnika, 18 (6), 1996, pp. 55-60.

9. Moskalenko, A.A., Kobasko, N.I., Tolmacheva, O.V., Totten, G.E., Webster, G.M. Quechants Characterization by Acoustical Noise Analysis of Cooling Properties of Aqueous Poly (Alkylene Glycol) Polymer Quenchants. Proc. of the 2nd Int. Conf. on Quenching and Control of the Distortion, (USA), 1996, pp.117-122.

10. Kobasko, N.I., Real and Effective Heat Transfer Coefficients (HTCs) Used for Computer Simulation of Transient Nucleate Boiling Processes during Quenching. Materials Performance and Characterization, 2012, 1 (1), doi: $10.1520 / \mathrm{mpc}-2012-0012$.

11. Logvynenko, P.N., Karsim, L.O., Riabov, S.V., Moskalenko, A.A., Kobasko, N.I., Oil quenchant, UA Patent № $104380,2016$.

12. Logvynenko, P.N., Moskalenko, A.A., Kobasko, N.I., Karsim, L.O., Riabov, S.V., Experimental Investigation of the Effect of Polyisobutilene Additives to Mineral Oil on Cooling Characteristics, Materials Performance and Characterization, 2016, 5 (1), doi: 10.1520/ mpc20150072.

13. Kobasko, N.I., Moskalenko, A.A., Logvinenko, P.N., Totten, G.E., Dobryvechir, V.V., New Era in Designing and Governing Cooling Intensity of Liquid Quenchants to Decrease Distortion, International Journal of Current Research, 2018, Vol.10, Issue 8, pp. 72631- 72636.

14. Kobasko. N.I., High Quality Steel vs Surface Polymeric Layer during Quenching, Lambert Academic Publishing, 2019, 102 p. ISBN: 978-613-9-45596-6.

15. Liscic, B., Measurement and Recording ofQuenching Intensity in Workshop Conditions Based on Temperature Gradients. Materials Performance and Characterization, 2016, 5 (1), 209-226. doi: 10.1520/ mpc20160007.

Отримано 30.05.2019 Received 30.05.2019 